SUSTAINABLE FORESTRY

COLLECTION 75-76, 2017
ODRŽIVO ŠUMARSTVO

ZBORNIK RADOVA 75-76, 2017

UDK $630 * 165.3: 582.475+630 * 232.12(497.11)=111$

Original scientific paper

\title{
VARIABILITY OF EPITHELIAL CELLS IN THE RESIN DUCT OF DOUGLAS-FIR NEEDLES
}

\author{
Vera LAVADINOVIĆ ${ }^{1}$, Ljubinko RAKONJAC ${ }^{1}$, Vukan LAVADINOVIĆ
}

\begin{abstract}
The research on the interactions between the genetic potential of introduced provenances and the environmental features of the locations in which the plantations were established was carried out in Douglas-fir plantations in Serbia. The twoway ANOVA was conducted in order to study the effects of the site conditions in the localities of Douglas-fir provenance tests in Serbia on the anatomical properties of needles. These analyses look into the effects of two factors (locality and provenance) on the number of epithelial cells in the resin duct of Douglas-fir needles.
\end{abstract}

Keywords: Douglas-fir, provenance, introduction, resin ducts, epithelial cells

\section{VARIJABILNOST BROJA EPITELNIH ĆELIJA U SMOLNOM KANALU ČETINA DUGLAZIJE}

\begin{abstract}
U kulturama duglazije u Srbiji obavljaju su istraživanja interakcija genetskog potencijala introdukovanih provenijencija sa ekološkim odlikama lokacija gde su kulture podignute. U cilju bližeg upoznavanja efekta interakcije stanišnih uslova lokaliteta, gde su osnovani provenijenični testove duglazije u Srbiji, na anatomska svojstva četina, obavljena je dvofaktorijalna analiza varijanse. U ovim analizama ispitivan je uticaj dva faktora (lokalitet i provenijencija) na broj epitelnih ćelija u smolnom kanalu četina duglazije.
\end{abstract}

Ključne reči: Duglazija, provenijencija, introdukcija,smolni kanali, epitelne ćelije

\footnotetext{
${ }^{1}$ Dr Vera Lavadinović, Dr Ljubinko Rakonjac, Institute of Forestry Belgrade, Kneza Višeslava 3, Serbia

${ }^{2}$ Faculty of Forestry Belgrade of University of Belgrade, Kneza Višeslava 1, Serbia

Contact author: Vera Lavadinović, Institute of Forestry Belgrade, Kneza Višeslava 3, Serbia, e-mail: veralava@eunet.rs
} 


\section{INTRODUCTION}

Douglas-fir (Pseudotsuga menziesii/Mirb. /Franco) is a very common tree species and accounts for $67 \%$ of 2238 samples taken from all site types (Pfister et al., 1977). It has the widest ecological amplitude of all western conifers and a notable diversity of genetic ecotypes (Moserud and Rehfeldt, 1990). The transfer of exotic tree species (Larsen and Syrack, 1946; S chober, 1959; Spurr, 1961; Schober, 1963; Kriek, 1974; Namkoog, 1979) entails the risk incurred by the lack of knowledge about the productivity and adaptability of introduced species to the environmental conditions of the sites which are outside its range of distribution.

Forest tree production is determined by the expression of physiological processes within specific environmental-genetic regimes. Temperature and soil are major environmental factors that affect the physiological processes of a plant and combined with the genetic variation within a seedling determine the type of organism that will be produced (Jensen and Gatherum, 1965; Dykstra and Gatherum, 1967; Schultz, 1970).

Douglas-fir can be described as a productive coniferous tree species with highly-valued wood, wide ecological amplitude and high-quality essential oils.

In chemotaxonomic terms, Douglas-fir belongs to a large group of aromatic medicinal plants that synthesize numerous and diverse biochemical metabolites. The mixtures of volatile products of Douglas-fir metabolism are the source of its distinctive scent and taste. They are contained in essential oils which can be found in all parts of the plant. Essential oils derived from Douglas-fir needles make significant raw materials both for the chemical industry and for its related industries, mainly because a great number of synthetic preparations that have the same effects as these oils have been found to have adverse side effects. Nowadays, essential oils have found the widest application in the pharmaceutical and cosmetic industry, where they are used as antiseptics, insecticides, deodorants and for masking the odor of synthetic products (Lavadinović, 2008).

The significance of the morphological and anatomical structure of needles, as well as the function and structure of resin ducts, have been analyzed by numerous authors (Matović and Lavadinović, 1999; Gerling et al., 2015;). Due to the high quality of its essential oils and their wide application in the cosmetic and pharmaceutical industry, Douglas-fir has also been the subject of numerous studies in Serbia (Tešević et al., 2002; Tešević and Lavadinović, 2009).

In order to investigate the genetic potential of Douglas-fir in its new ecosystems of Serbia, the Institute of Forestry in Belgrade has established several experimental plots of Douglas-fir of different provenances originating in North America.

The primary goal of the experiments (on the mountain of Juhor near Jagodina and in the village of Tanda near Bor) was to determine the effects of the geographical parameters of the original localities of Douglas-fir provenances their geographical latitude, geographical longitude and altitude on the growth of trees with the aim of selecting the most adaptable provenances to be used in the cultivation on similar sites. 


\section{MATERIAL AND METHODS}

The study area covered Douglas-fir provenance tests established in Central Serbia on the mountain of Juhor and in the village of Tanda located at the foot of the mountain massif of Deli Jovan in Eastern Serbia. Douglas-fir seedlings were raised in the nursery of the Institute of Forestry in Belgrade from the seeds native to North America. The seeds originate from a part of the natural range of Douglasfir distribution with 20 provenances that differ in the latitude, longitude and altitude (Table 1, Lavadinović,V., Koprivica, M. 1996)).

The experiment on the mountain of Juhor was established on a beech site (Fagetum moesiaca montanum Jov. 1976) on acid brown soil (dystric cambisol) over gneiss. 'Tanda' sample plot is located in FMU 'Stol' in 'Bor' Forest Administration on the site of oak, Hungarian oak and Turkey oak (Querceto conferte cerris Rud.) on brown acid soil and sierozem (Lavadinović, 2008).

Table 1. Geographical coordinates of the tested Douglas-fir provenances (Lavadinović, V., Koprivica, M. 1996)

\begin{tabular}{|l|c|c|c|c|}
\hline Provenance number & $\begin{array}{c}\text { Our } \\
\text { mark }\end{array}$ & $\begin{array}{c}\text { Latitude } \\
\left({ }^{\mathbf{0}} \mathbf{N}\right)\end{array}$ & $\begin{array}{c}\text { Longitude } \\
\left({ }^{\mathbf{6}} \mathbf{E}\right)\end{array}$ & $\begin{array}{c}\text { Altitude } \\
(\mathbf{m})\end{array}$ \\
\hline & & & & \\
\hline Oregon 205-15 & 1 & 43.7 & 123.0 & 750 \\
\hline Oregon 205-14 & 2 & 43.8 & 122.5 & 1200 \\
\hline Oregon 202-27 & 3 & 45.0 & 122.4 & 450 \\
\hline Oregon 205-38 & 4 & 45.0 & 121.0 & 600 \\
\hline Washington 204-07 & 9 & 49.0 & 119.0 & 1200 \\
\hline Oregon 205-13 & 10 & 43.8 & 122.5 & 1050 \\
\hline Oregon 205-18 & 11 & 44.2 & 122.2 & 600 \\
\hline Oregon 202-22 & 12 & 42.5 & 122.5 & 1200 \\
\hline Washington 202-17 & 15 & 47.6 & 121.7 & 600 \\
\hline Oregon 201-10 & 16 & 44.5 & 119.0 & 1350 \\
\hline Washington 201-06 & 17 & 49.0 & 120.0 & 750 \\
\hline Oregon 202-19 & 18 & 45.3 & 123.8 & 300 \\
\hline Oregon 205-11 & 20 & 45.0 & 123.0 & 150 \\
\hline New Mexico 202-04 & 22 & 32.9 & 105.7 & 2682 \\
\hline New Mexico 202-10 & 23 & 36.0 & 106.0 & 2667 \\
\hline Oregon 202-31 & 24 & 44.3 & 118.8 & 1500 \\
\hline Oregon 205-29 & 26 & 42.6 & 122.8 & 900 \\
\hline Oregon 205-08 & 27 & 42.7 & 122.5 & 1050 \\
\hline Oregon 204-04 & 30 & 45.0 & 121.5 & 900 \\
\hline Washington 205-17 & 31 & 47.7 & 123.0 & 300 \\
\hline
\end{tabular}

A two-way analysis of variance of the number of epithelial cells in the resin ducts was carried out in order to identify the provenances whose genetic potential is most suited to the environmental conditions of the forest communities on whose sites the experiments were established.

Fresh needles were fixed in 50\% ethyl alcohol and transported to the laboratory, where permanent anatomical cross-sections of 30 randomly selected needles were made. Permanent anatomical preparations of $17 \mu \mathrm{m}$ thickness were cut in the middle of the needle using a microtome. They were then dyed by safranin red and toluidine blue and washed with water. This was followed by dehydration with ethyl alcohol, increasing the alcohol concentration from $50 \%$ to $96 \%$. The 
cross-sections were eventually fixed with xylol for several hours, after which the needles were glued to the slides using Canada balsam, covered with cover glass and dried in a dryer at a temperature of $60^{\circ} \mathrm{C}$. Three weeks later, the number of epithelial cells in the resin duct was counted (Paraffin processing method).

\section{RESULTS AND DISCUSSION}

Table 2 and Graphs 1 and 2 show the results of the two-way analysis of variance (locality x provenance) for the number of epithelial cells in the resin ducts of Douglas-fir needles at both localities.

Table 2. Two-way (locality x provenance) ANOVA for the number of epithelial cells in the resin ducts

\begin{tabular}{|l|c|c|c|c|c|}
\hline $\begin{array}{c}\text { Source of } \\
\text { variation }\end{array}$ & $\begin{array}{c}\text { Sum of } \\
\text { squares }\end{array}$ & $\begin{array}{c}\text { Degree of } \\
\text { freedom }\end{array}$ & Variance & F-ratio & p-value \\
\hline A: Locality & 8.14 & 1 & 8.1 & 10.57 & 0.013 \\
\hline B: Provenance & 156.856 & 5 & 31.3711 & 40.94 & 0.000 \\
\hline Interaction $\mathrm{AB}$ & 311.833 & 5 & 62.3667 & 81.39 & 0.000 \\
\hline Errors & 266.667 & 348 & 0.766284 & & \\
\hline Total & $\mathbf{7 4 3 . 4 5 6}$ & $\mathbf{3 5 9}$ & \\
\hline
\end{tabular}

The results of the analysis of variance (Table 2) show that:

a) there are statistically significant differences in the mean values of the number of epithelial cells between the site of Juhor and the site of Tanda;

b) there are statistically significant differences in the mean values of the number of epithelial cells between provenances;

c) in certain provenances, the interaction between the 'locality' factor and 'the provenace` factor affects the mean value of the number of epithelial cells.

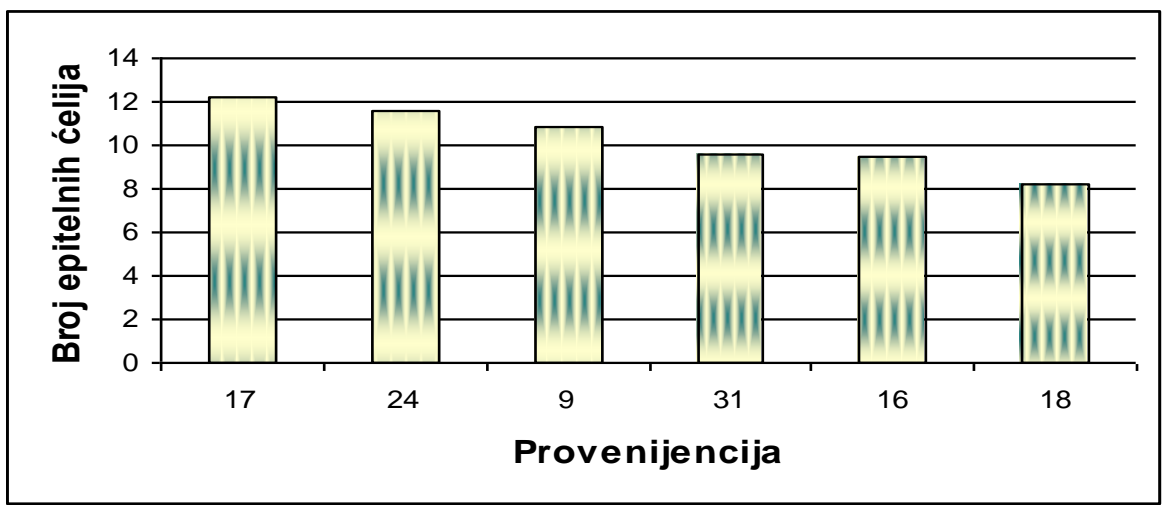

Graph 1. Interprovenance variation of the number of epithelial cells in the resin duct at Juhor 


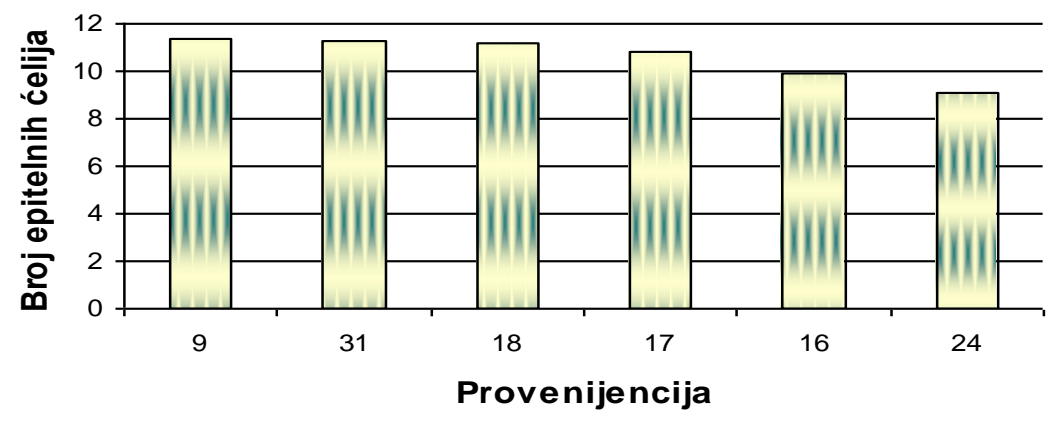

Graph 2. Interprovenance variation of the number of epithelial cells in the resin duct at Tanda

\section{The effects of locality on the number of epithelial cells}

Table 3. MSD test of the effects of locality on the number of epithelial cells

\begin{tabular}{|c|c|c|c|c|}
\hline Locality & Sample size & Mean value & $\begin{array}{c}\text { Difference error } \\
\text { mean }\end{array}$ & Homogeneous groups \\
\hline Juhor & 180 & 10.3111 & 0.0652467 & $X$ \\
\hline Tanda & 180 & 10.6111 & 0.0652467 & $X$ \\
\hline \multicolumn{2}{l}{ Comparison } & Differences & $+/-$ Limits \\
\hline \multicolumn{2}{l}{ Juhor-Tanda } \\
*
\end{tabular}

* statistically significant difference

Table 1. MSD test of the effects of the locality on the number of epithelial cells

\begin{tabular}{|c|c|c|c|c|}
\hline Locality & Sample size & Mean value & $\begin{array}{c}\text { Difference error } \\
\text { mean }\end{array}$ & $\begin{array}{c}\text { Homogeneous } \\
\text { groups }\end{array}$ \\
\hline 16 & 60 & 9.7 & 0.113011 & $\mathrm{X}$ \\
\hline 18 & 60 & 9.7 & 0.113011 & $\mathrm{X}$ \\
\hline 24 & 60 & 10.3667 & 0.113011 & $\mathrm{X}$ \\
\hline 31 & 60 & 10.4333 & 0.113011 & $\mathrm{X}$ \\
\hline 9 & 60 & 11.0667 & 0.113011 & $\mathrm{X}$ \\
\hline 17 & 60 & 11.5 & 0.113011 & $\mathrm{X}$ \\
\hline \multicolumn{2}{|c|}{ Comparison } & \multicolumn{2}{|c|}{ Differences } & +/- Limits \\
\hline \multicolumn{2}{|c|}{$9-16$} & \multicolumn{2}{|c|}{$* 1.36667$} & 0.314337 \\
\hline \multicolumn{2}{|c|}{$9-17$} & \multicolumn{2}{|c|}{$*-0.433333$} & 0.314337 \\
\hline \multirow{2}{*}{\multicolumn{2}{|c|}{ 9-18 }} & \multicolumn{2}{|c|}{$* 1.36667$} & 0.314337 \\
\hline & & \multicolumn{2}{|c|}{$* 0.7$} & 0.314337 \\
\hline \multicolumn{2}{|c|}{$9-31$} & \multicolumn{2}{|c|}{$* 0.633333$} & 0.314337 \\
\hline \multicolumn{2}{|c|}{$16-17$} & \multicolumn{2}{|c|}{$*-1.8$} & 0.314337 \\
\hline \multicolumn{2}{|c|}{$16-18$} & \multicolumn{2}{|c|}{0.0} & 0.314337 \\
\hline \multicolumn{2}{|c|}{$16-24$} & \multicolumn{2}{|c|}{$*-0.666667$} & 0.314337 \\
\hline \multicolumn{2}{|c|}{$16-31$} & \multicolumn{2}{|c|}{$*-0.733333$} & 0.314337 \\
\hline \multicolumn{2}{|c|}{$17-18$} & \multicolumn{2}{|c|}{$* 1.8$} & 0.314337 \\
\hline \multicolumn{2}{|c|}{$17-24$} & \multicolumn{2}{|c|}{ * 1.13333} & 0.314337 \\
\hline \multicolumn{2}{|c|}{$17-31$} & \multicolumn{2}{|c|}{$* 1.06667$} & 0.314337 \\
\hline \multicolumn{2}{|c|}{$18-24$} & \multicolumn{2}{|c|}{$*-0.666667$} & 0.314337 \\
\hline \multicolumn{2}{|c|}{$18-31$} & \multicolumn{2}{|c|}{$*-0.733333$} & 0.314337 \\
\hline \multicolumn{2}{|c|}{$24-31$} & \multicolumn{2}{|c|}{-0.0666667} & 0.314337 \\
\hline
\end{tabular}

* statistically significant difference

The results shown in Table 3 point to statistically significant differences in the mean number of epithelial cells of Douglas-fir needles obtained from Juhor and Tanda localities. The average number of epithelial cells in the Douglas-fir needles 
from Tanda locality (10.61) is significantly higher than the number of these cells in the needles of Douglas-fir trees from Juhor locality (10.31). The range of variation of this property for the analyzed provenances is shown Graphs 1 and 2. Using the MSD test, we got a deeper insight into the effects of the characteristics of the locality where the provenance tests were conducted on the number of epithelial cells of Douglas-fir needles.

The results presented in Table 4 show that there are statistically significant differences in the number of epithelial cells between provenances. However, the results of the MSD test indicate that provenances 16 and 18, 24 and 31 are homogeneous since there are no statistically significant differences in the mean values of the number of epithelial cells.

\section{CONCLUSIONS}

On the basis of the examinations carried out through Douglas-fir provenance tests on the (Fagetum moesiaca montanum Jov. 1976) site on acid brown soil (dystric cambisol) over gneiss and on the site of oak, Hungarian oak and Turkey oak (Querceto conferte cerris Rud.) on brown acid soil and sierozem, we can draw the following conclusions:

- there are statistically significant differences in the mean values of the number of epithelial cells between the localities of Juhor and Tanda;

- there are statistically significant differences in the mean values of the number of epithelial cells between provenances;

- in certain provenances, the interaction between the 'locality' factor and 'the provenace factor affects the mean value of the number of epithelial cells.

- the average number of epithelial cells in the needles of Tanda locality is significantly higher than the number of these cells in the needles of Douglas-fir trees of Juhor locality.

- there are statistically significant differences in the number of epithelial cells between provenances. However, the results of the MSD test indicate that the provenances 16 and 18, 24 and 31 are homogeneous because they don't show statistically significant differences in the mean values of the number of epithelial cells and there is an interaction between the variability factors (locality and provenance), i.e., a change in one variability factor affects the change in the treatment of another factor.

\section{Acknowledgments}

This paper was realized as a part of the project 'Studying climate change and its influence on the environment: impacts, adaptation and mitigation` (43007) financed by the Ministry of Education and Science of the Republic of Serbia within the framework of integrated and interdisciplinary research for the period 2011-2017.

\section{Acknowledgments}

This paper was realized as a part of the project "The development of technological processes in forestry in order to realize the optimal forest cover" (TR31070) financed by the Ministry of Education and Science of the Republic of Serbia within the framework of integrated and interdisciplinary research for the period 2011-2017. 


\section{LITERATURE}

Dykstra, G.F., and Gatherum,G.E. (1967): Physiological variation of Scots pine seedlings in relation to provenance and nitrogen. Iowa State College Journal of Science 41:487-502.

Gerling N.V., Punegov, V.V., and Gruzdev I.V. (2015) : Component composition of essential oils and ultrastructure of secretory cells of resin duct needles Juniperus communis (Cupressaceae). Sibirskij Lesnoj Zhurnal (Siberian Journal of Forest Science) 6: 62-69.

Jensen, K.F., and Gatherum, G.E. (1965): Effect of temperature, photoperiod and provenance on growth and development of Scots pine seedling. Journal of Forest Science 11:189-199.

Kriek, W. (1974): Douglas-fir IUFRO provenances in the Netherlands. 1966/1967 series. Nederlands Bosbouwproefstn. Tijdschrift 46 (1): 1-14.

Larsen, C., and Syrack (1946): Forest tree breeding and Danish experiments. Ned. Bosbouwproefstn. Tijdschr. 18: 246-263.

Lavadinović,V., Koprivica, M. (1996): Tracheid Width of Different Douglas fir (Pseudotsuga taxifolia Britt.) Provenances in Test Plantations in the Region of Serbia. Second International Conference on the Development of Wood Science Technology and Forestry, Proceedings, pp. 287-296, Sopron, Hungary.

Lavadinović Vera (2008): Ekološke komponente varijabilnosti duglazije (Pseudotsuga menziesii/Mirb./Franco) u provenijeničnim ogledima u Srbiji. Doktorska disertacija, odbranjena na Šumarskom fakultetu, Univerziteta u Beogradu. 630*165.3: 630*232.12]: 582.475 Pseudotsuga menziesii (497.11) (043.3). Strana 193.

Lavadinović Vera (2008): Ecological components of the variability of Douglas-fir (Pseudotsuga menziesii/Mirb./Franco) in provenenance tests in Serbia. $\mathrm{PhD}$ thesis, defended at the Faculty of Forestry, University of Belgrade. 630*165.3: 630*232.12]: 582.475 Pseudotsuga menziesii (497.11) (043.3). Pages 193. (Translation)

Matović, M., Lavadinović, V. (1999): Essential oil of the fruit of Juniperus Communis L. growing in Yugoslavia. Journal of Essential oil Bearing Plants 3 (2): 101-107.

Monserud, R.A., Rehfeldt, G.E. (1990): Genetic and environmental component of variation of site index in inland Douglas fir. Journal of Forest Science 36: 1-9.

Namkoong, G. (1979): Introduction to quantitative genetics in forestry. Technical Bulletin 1588. Washington, DC: U.S. Department of Agriculture, Forest Service: 342.

Pfister, R.D., Kovalchik, B.L., Arno, S.F., and Presby, R.C. (1977): Forest habitat types of Montana. [online] Available at: https://www.cabdirect.org/cabdirect/abstract/19781940272 (Accessed 5 December 2017).

Schober, R. (1959): Results of Douglas-fir provenance tests in Germany, Holland, and Denmark, Allgemeine Forst und Jagdzeitung 14 (8): 145-152.

Schober, R. (1963): Experiences with the Douglas-fir in Europe. World Consultations for Genetics and Tree Improvement, Stockholm, FAO/FORGEN 63-4/5: 18.

Schultz, R. C. (1970): The effect of soil moisture and day temperature on photosynthesies, growth and needle anatomy of Scots Pine seedling.Retrospective Thesses and Dissertation, 4358, Iowa. 
Spurr, S.H. (1961): Observations on Douglas-fir in New Zealand. New Zeleand Forest Service, Forest Research Institute Tech. Paper 38: 16.

Tešević,V., Djoković,D., Milosavljević,S., Lavadinović,V., Matović,M., Vujević,D. (2002): Etarsko Ulje Četina Duglazije (Pseudotsuga Menziesii Mirb. Franco) iz različitih provenijencija. Institut Za Proučavanje Lekovitog Bilja: Dr Josif Pančić" Zbornik Radova 22: 53-57.

Tešević, V., Djoković, D., Milosavljević, S., Lavadinović, V., Matović, M., Vujević, D., (2002): Essential oil of (Pseudotsuga Menziesii Mirb. Franco) from various provenances. Institute for the Study of Medicinal Herbs: Dr. Josif Pančić Proceedings 22: 53-57 (Translation)

Tešević,V., Lavadinović, V. (2009): Analysis and antifungal activity essential oil of Douglas fir (Pseudotsuga menziesii) from Serbia. Journal of the Serbian Chemical Society 74 (10):1035-1040

\title{
VARIABILITY OF EPITHELIAL CELLS IN THE RESIN DUCT OF DOUGLAS- FIR NEEDLES
}

\author{
Vera LAVADINOVIĆ, Ljubinko RAKONJAC, Vukan LAVADINOVIĆ
}

\section{Summary}

Coniferous tree species are rich in essential oils, which have a protective role for the plant itself and a wide use in the pharmaceutical, cosmetic and food industry.

The resin is an organic liquid containing terpenes, resin acids and other compounds found in the resin ducts of all plant parts. Resin ducts are surrounded by epithelial cells. Aromatic effects of essential Douglas-fir oils make this type of conifer very popular in urban greening and green area establishment. The study deals with the effects of two factors (locality and provenance) on the number of epithelial cells in the resin duct.

\section{VARIJABILNOST BROJA EPITELNIH ĆELIJA U SMOLNOM KANALU ČETINA DUGLAZIJE}

Vera LAVADINOVIĆ, Ljubinko RAKONJAC, Vukan LAVADINOVIĆ

\section{Rezime}

Četinaske vrste drveća su bogate etarskim uljima, koje imaju zaštitnu ulogu za samu biljku i široku upotrebnu u farmaceutskoj, kozmetičkoj i prehrambenoj industriji.

Smola je organska tečnost koja sadrži terpene, smolne kiseline i druga jedinjenja koje se nalaze u svim delovima biljke u smolnim kanalima. Smolni kanali su obloženi epitelnim ćelijama. Etarska ulja iz četina duglazije zbog aromatičnog efekta čine ovu vrstu četinara vrlo popularnom za urbano ozelenjavanje i formiranje zelenih masiva. U ovim analizama ispitivan je uticaj dva faktora (lokalitet i provenijencija) na broj epitelnih ćelija u smolnom kanalu. 